\title{
Connecting political ecology of health and disease with 'structural stigmatization': declining use of forest foods and medicines in Kédougou, Senegal
}

\author{
Taylor K. Lucey ${ }^{1}$ \\ Kerry E. Grimm \\ Oregon State University, USA \\ Northern Arizona University, USA
}

\begin{abstract}
Recent political ecology (PE) frameworks have evolved to identify power disparities that have consequences for human health and disease development. These power disparities can lead to unequal access to health information, natural resources (e.g. farmland, clean water), micronutrients, healthcare, and other elements necessary to maintain healthy bodies and reduce risk of disease. While many PE and political ecology of health and disease (PEHD) frameworks examine access in terms of limitations, few examples highlight effects from increased access to resources. This article uses a PEHD lens to examine how diets and health in rural Kédougou, Senegal are influenced by increased access to globalized foodstuffs and stigmatization of local foods and medicines. A better understanding of dietary decision-making is critical in understudied regions such as Senegal because West Africa has a rapidly expanding population and is projected to be among regions of the world that are most burdened with non-communicable diseases (NCD). We used qualitative methods to: 1) describe current and historic diets in Kédougou; 2) identify perceived changes about diet, health, and access to resources; and 3) understand what might be influencing these changes. Our article shows that increased access and limited access are interconnected because increased, regular access to globalized foods and medicines could factor into reduced access to local foods and medicines. We found that social context strongly influenced use of local forest foods and medicines, even leading to a gradual stigmatization of using these resources.
\end{abstract}

Keywords: political ecology of health and disease, stigmatization, access, globalization, food, noncommunicable disease, West Africa

\section{Résumé}

Les cadres de recherche en « political ecology » (PE) ont évolué pour identifier les disparités de pouvoir ayant des conséquences sur la santé humaine et les maladies. Ces disparités de pouvoir peuvent conduire à un accès inégal à l'information sur la santé, aux ressources naturelles (par exemple, les terres agricoles, l'eau potable), les micronutriments, les soins de santé et d'autres éléments nécessaires pour maintenir un corps sain et réduire le risque de maladie. Alors que de nombreux cadres d'PE et de la « political ecology of health and disease (écologie politique de la santé et de la maladie) » (PEHD) montrent les effets des imitations sur l'accès, peu d'exemples montrent ce qui se passe lorsqu'il y a un accès accru aux ressources. Cet article utilise une lentille PEHD pour examiner comment les régimes alimentaires et la santé dans les zones rurales de Kédougou, au Sénégal, sont influencés par l'accès accru aux denrées alimentaires mondialisées et la stigmatisation des aliments et des médicaments locaux. Une meilleure compréhension de la prise de décision alimentaire est

\footnotetext{
${ }^{1}$ Taylor K. Lucey, Researcher, College of Forestry, Oregon State University, USA. Email: keachlucey "at" gmail.com. Dr. Kerry E. Grimm, Director of Social Science Research, Ecoculture. Adjunct Research Faculty, School of Earth and Sustainability; Center for Adaptable Western Landscapes, Northern Arizona University, USA. Email: Kerry.grimm "at" nau.edu. We would like to thank the informants who volunteered their time and expertise, without whom this research would not have been possible. We also would like to thank Peace Corps Senegal, Macire Diallo for his assistance with Pulaar translation, and Jessica Archibald for translating the abstract into Spanish. Finally, we would like to thank Dr. John Bliss for his support and guidance.
} 
essentielle dans les régions peu étudiées comme le Sénégal, car l'Afrique de l'Ouest a une population en expansion rapide et devrait faire partie des régions du monde les plus touchées par les maladies non transmissibles (MNT). Nous avons utilisé des méthodes qualitatives pour : 1 ) décrire les régimes alimentaires actuels et historiques à Kédougou; 2) identifier les changements perçus concernant l'alimentation, la santé et l'accès aux ressources; et 3) comprendre ce qui pourrait influencer ces changements. L'article montre qu'un accès accru et un accès limité sont interconnectés. Un accès accru et régulier aux aliments et aux médicaments mondialisés pourrait se traduire par un accès réduit aux aliments et aux médicaments locaux. Nous avons constaté que le contexte social influençait fortement l'utilisation des aliments et des médicaments forestiers locaux, conduisant même à une stigmatisation progressive de l'utilisation de ces ressources.

Mots-clés: écologie politique de la santé et de la maladie, stigmatisation, accès, mondialisation, alimentation, maladies non transmissibles, Afrique de l'Ouest

\section{Resumen}

Los marcos recientes de ecología política (EP) han evolucionado para identificar las disparidades de poder que tienen consecuencias para la salud humana y el desarrollo de enfermedades. Estas disparidades de poder pueden crear un acceso desigual a los recursos naturales (e.g., tierras agrícolas, agua limpia), micronutrientes, atención médica, información de salud y otros elementos necesarios para mantener cuerpos sanos y reducir el riesgo de enfermedades. Si bien muchos marcos de EP y ecología política de la salud y la enfermedad (EPSE) examinan el acceso en términos de limitaciones, pocos ejemplos destacan los efectos de un mayor acceso a los recursos. Este artículo utiliza una lente PEHD para examinar cómo las dietas y la salud en las zonas rurales de Kédougou, Senegal están influenciadas por un mayor acceso a los alimentos globalizados y la estigmatización de los alimentos y medicamentos locales. Un mejor conocimiento de la toma de decisiones dietéticas es fundamental en regiones poco estudiadas como Senegal porque África Occidental tiene una población en rápido crecimiento y porque se prevé que se encuentre entre las regiones del mundo más afectadas por las enfermedades no transmisibles (ENT). Usamos métodos cualitativos para: 1) describir las dietas actuales e históricas en Kédougou; 2) identificar los cambios percibidos sobre la dieta, la salud y el acceso a los recursos; y 3) comprender qué podría estar influyendo en estos cambios. Nuestro artículo muestra que un mayor acceso y un acceso limitado están interconectados porque un mayor acceso regular a alimentos y medicinas globalizados podría ser un factor en el acceso reducido a alimentos y medicinas locales. Descubrimos que el contexto social influyó fuertemente en el uso de alimentos y medicinas forestales locales, llegando incluso a una estigmatización gradual del uso de estos recursos.

Palabras claves: la ecología política de la salud y la enfermedad, estigmatización, acceso, globalización, alimento, los enfermedades no transmisibles, África Occidental

\section{Introduction}

Most residents in Kédougou Region, the southeasternmost region of Senegal, live rural, agrarian lives (ANSD, 2015). Kédougou Region's population is rapidly growing, as well as its gold mining industry, which has initiated a wave of changes: infrastructure development, shifting livelihoods, growing local economies, and increased access to globalized goods. Using a political ecology of health and disease (PEHD) lens, we explore these changes in Kédougou, with a particular focus on increased access to globalized medicines and foods. PEHD research has examined the influence of external forces on health, disease development, and perceptions as they relate to accessing local food resources, micronutrient-rich foods, and health education (King, 2010; Mayer 1996; Nichols, 2015; Richmond et al., 2005; Yates-Doerr, 2015). In 2017, a special issue of Journal of Political Ecology concluded that in addition to examining health perceptions, disease development serves as a "powerful analytical point or entry" into the socioeconomic and political disparities of achieving healthy bodies (Connolly et al., 2017, p.7). In this article, we use dietary shifts and emerging concerns about disease as entry points to uncover forces that might be influencing dietary decision-making in Kédougou.

We approach perceptions of changing diets, health, and disease in Kédougou through understanding access to resources. 'Access' in political ecology (PE) is often explored in terms of limitations and barriers to resources or power (Ribot \& Peluso, 2003). We reverse the typical PE 'limited access' lens and instead, we examine perceptions about widespread increased access to globalized foods and medicines. We examine access 
not as a function of whether individuals have access to resources, but rather how individuals access resources, who or what is influencing decision-making around accessible resources, and the unintended health consequences of that process. Dependence on globalized foodstuffs not only restricts access to diverse foods but can also result in food shortages and high prices during global economic instability (Resnick, 2013; Rosen \& Shapouri, 2008). Increased dependency on globalized foods combined with urbanization has made it more challenging for people to access 'wild foods', or local, nutritionally valuable forest foods (Sneyd, 2013).

Our article explores how political, economic, and social forces might be affecting access to - and use of - forest foods and medicines in Kédougou, and subsequently informants' perceptions of their health. We also dig into social barriers to forest foods and medicines, using a "structural stigmatization" framework (Hatzenbeuhler \& Link, 2014; Raghavan et al., 2008). Stigmatization, especially of marginalized individuals, has emerged in recent literature as a barrier to accessing resources (e.g. mental health resources) once it has become embedded in social norms (Raghavan et al., 2008; Rose, 2017). While it would be difficult to prove causation between poor health or disease and stigmatized groups, it is important to identify power dynamics that can influence decision-making that might lead to increased disease morbidity. Therefore, in this study, our research objectives were to: 1) describe diets in the study region, 2) identify perceived changes in diet, health, and access to resources, and 3) understand what might be influencing these changes.

\section{Political ecology and access}

PE literature historically has focused on political, economic, and social dimensions that interact with one another and the environment at a variety of scales (Blaikie, 1985). These studies have also typically focused on land use change and access to natural resources. Our research uses Ribot and Peluso's (2003) definition of 'access', which refers to an individual's ability to derive benefits from things, including, for example, the environment, social benefits, and economic markets. Access is often unequal because some individuals, institutions, and governments control how things are accessed, while other individuals can only gain access through those institutions or individuals with control (Ribot \& Peluso, 2003). This relationship between power and control can affect 'access' through limitations, restrictions, or barriers to natural resources, which shape the landscape (Peluso, 1996; Ribot \& Peluso, 2003). For example, Bennett et al. (2018) described accelerating rates of deforestation in the Peruvian Amazon as private transnational companies turned to regions outside of southeast Asia for palm oil plantations. The increased production of the cash crop and encouragement of community relationships with privatized producers exacerbated land degradation and created unequal access to subsistence farming for local communities.

Our research employs the concept of access to examine who has access to forest foods and medicines in Kédougou, Senegal, and how access to those resources is obtained or maintained. To increase access to economic opportunities across the country, international investments in Kédougou Region have been rising in recent decades. In 2016, Senegal's President, Macky Sall, revised the 2003 mining code, which allowed mining companies to own $100 \%$ of their shares, attracting more foreign investors (Dorin \& Welsh, 2017; Fall, 2015). While small-scale gold mining was common in Senegal for at least half a century (other sources suggest multiple centuries), industrial-scale mining has placed new pressures on land use, as well as local social and political environments (Daffé, 2011; Persaud et al., 2017; USAID, 2009). Commercial gold mining was designed to bring social funds, development, and jobs. Thus far, these needs have not been addressed and instead, mining has exacerbated extreme differences between rich and poor in the region (USAID, 2009). Gold mining expansion has attracted migrants from neighboring countries as well as Kédougou residents to the potential income-generating opportunities that mining towns and Kédogou City have to offer. Though access to new economic opportunities is climbing in some areas of the region, access to other essential needs such as healthcare, have yet to catch up. For example, Kédougou's maternal death rate is twice as high as Senegal's national average, while life expectancy in the region is almost ten years lower than the average (ANSD, 2015). Furthermore, national policies have been less focused on micronutrient deficiencies and more on addressing caloric security. While usually well-intentioned, some policies aim solely to ramp up crop production, disregarding what might be causing widespread malnutrition (Remans et al., 2014). Discussions about political disparities that influence malnutrition are limited in PE literature (Köpke, 2021). 


\section{Globalized and delocalized diets}

Overlapping with the concept of access is globalization, which is the ease with which products, technologies, capital, populations, knowledge, etc. can be shared or traded internationally (Shetty, 2003). We primarily focus on the influence of globalized economies and food systems. Globalization can lead to external relationships with larger economies that increase access to capital, new products, capitalism, and global market opportunities (Kennedy et al., 2004; Nichols, 2015). Economic growth is not inherently negative; however, a globalized world where economic, political, and social forces are interconnected can result in pressure at local scales. For example, Nichols (2015) found that new policies changing agricultural production and had cascading effects on livelihoods in India. Though Nichols (2015) found that people were earning money and able to purchase food, there were unintended ecological and health consequences. In Kédougou Region, local forest foods and medicines are still physically accessible, but consumption of globalized foods such as white rice, palm oil, vegetable oil, white sugar, and bouillon seasoning (shortened to bouillon), are pervasive (Ba et al., 2009). Though some globalized foods are flavorings or seasoning, rather than foodstuffs, this article refers to all of these as imported foods to identify the trend towards globalized consumption.

International trade markets make it easy for transnational companies to introduce cheap, packaged globalized food products across the globe and into rural places (Popkin, 2017). Large corporations, such as Nestle and Alibaba, have expedited dietary substitution that has led to a gradual delocalization of diets (Olayiwola et al., 2004). Delocalization occurs when local foods become reduced or commodified, or access to local foods is limited (Kennedy et al., 2004; Pelto \& Pelto, 1983). There is evidence that 'new' foods can limit access to local foods because local foods are substituted for imported ones (Nichols, 2015, 2017; Yates-Doerr, 2015). Bouillon is a particular focus of this article and it should be noted that although most bouillon is imported, there is one brand, Adja, that is manufactured in Dakar, Senegal.

In Senegal, homogenized diets are widespread and there has additionally been dramatic land use change in the last several decades due to shifting agricultural practices during- and post-French colonization (Remans et al., 2014). For example, the peanut was introduced during French colonization and in exchange for selling peanuts grown along the Senegal River Basin back to France, the French introduced imported white rice from Vietnam and Thailand (Resnick, 2013). Today, both rice and peanuts are considered staple foods and are the base of Senegal's national dish, maffe tiga (white rice with peanut sauce, flavored with salt and bouillon). This shift to both producing and consuming white rice and peanuts was a step towards novel, yet nutritionally poor foods. Nutritionally poor foods and lack of dietary diversity can in turn lead to weakened immune systems and disease.

\section{Globalized health and disease}

There are correlations between homogenized diets and development of non-communicable diseases (NCD), such as type 2 diabetes and hypertension (Popkin, 2017). Global dietary trends have ripple effects at local scales and further exacerbate health and disease disparities (Nichols, 2015; Richmond et al., 2005). Though not explicitly identified in terms of increased access to globalized foods, Yates-Doerr (2015) found links between globalized diets and increased consumption of calorically dense foods, which led to nutrient deficiencies in Guatemala. Yates-Doerr (2015) explored connections between NCD-development and capitalism, increased agricultural production, and increased dependence on purchased foods. This interdependent relationship between capitalism and globalized economies made it difficult for people to continue living a subsistence farming lifestyle. Yates-Doerr (2015) identified that a loss of subsistence farming resulted in lost access to locally produced foods because crops were sold, rather than consumed at household scales. Another study found that urbanization in Cameroon resulted in lost access to "wild foods", such as local fruits. These foods were too expensive in the city, which resulted in a dependency on nutritionally-poor, imported foods such as white rice (Sneyd, 2013). Not explicitly identified in Yates-Doerr (2015), Sneyd (2013), or other studies with similar findings (e.g. Nichols, 2015), is a context in which people gain access to globalized

resources, yet maintain physical access to subsistence farming, forest foods, and forest medicines. We aim to address this gap in the literature because many of the "wild" forest foods and medicines that people in Kédougou 
Region consumed in the past, are still physically available, but there is additionally widespread consumption of globalized foods and medicines.

While it is tempting to view changes to land use and forest access as environmental, these should be regarded as political-economic changes (Köpke, 2021). Land use change that prevents access to natural resources is driven by a political decision that erodes both economic opportunities and access to local, diverse foods. Through a case study in British Columbia, Canada, Richmond et al. (2005) suggested that a political ecology of disease framework helped identify where institutional processes disregarded the decision-making processes of 'Namigs First Nation for salmon resource access. Richmond et al. (2005) suggested a political ecology of disease framework helped identify where institutional processes disregarded 'Namigs First Nation people in decision-making processes about accessing salmon resources. While Richmond et al. (2005) found there was an overall decline in community health from lack of access to salmon, assertions could be made that the physical health of 'Namigs First Nation peoples would likely suffer due to a lack of nutritional salmon or economic opportunity to sell salmon. If the social, economic, political, and environmental status/es of an individual or community are compromised, this can additionally result in increased vulnerabilities to poor health and reduce the ability to adapt during changing conditions or a crisis (Leatherman 2005).

PEHD literature has additionally focused on the lack of access to health information or education at the local level, particularly amidst global health and disease crises. For example, King (2010) examined the AIDS crisis in South Africa and determined the government did not disseminate health information transparently, which influenced the spread of the disease. Connolly (2017) used concerns about the avian and bird flu epidemic as an avenue for exploring the growing interest in 'swiftlet farming' in urban Malaysia; the popularity of this economic endeavor having largely to do with the climbing global prices for swiftlet nests. A PEHD framework allows for exploration of access beyond physical or economic components of medical treatment or healthy foods; PEHD can be used to uncover how resources are social accessed.

\section{Social access and 'structural stigmatization'}

There are lingering knowledge gaps about the types of social barriers that might be preventing access to locally collected foods, and how that influences health. We want to address this gap through connecting PEHD frameworks with "structural stigmatization" (Hatzenbeuhler \& Link, 2014) because stigma may not only exist in local communities but might also exist within institutions. If decision-making institutions and governments are reinforcing stigma, accessing healthcare or health information may be more challenging for stigmatized groups (Sultana, 2012). Furthermore, stigmatized groups often face environmental, social, and other factors that increase risk of co-morbidities (Singer et al., 2017).

Structural stigmatization is defined as, "societal-level conditions, cultural norms, and institutional policies that constrain opportunities, resources, and wellbeing of the stigmatized" (Hatzenbeuhler \& Link 2014, p.2). Where stigma is embedded in health institutions and cultural norms, health and healthcare inequalities can persist and continue to be reinforced by institutions and individuals with decision-making power (Raghavan et al., 2008; Sultana, 2012). Rose (2017) noted that persistent stigma around homelessness influenced a sense that cleaning up homeless individuals is a necessary part of community health - not just in terms of social cleanliness, but also in the physical environment of the community. Contexts in which some groups have direct access to resources while others can only access resources through another group with control reinforces power imbalances between social groups. Social norms, culture, and relationships are key to understanding how these power imbalances form.

It would be difficult to prove a causal relationship between stigma and poor health because there are innumerable factors that affect every individual's health, including genetic predispositions. However, there have been studies about health disparities between stigmatized and non-stigmatized groups, notably in the context of broad social policy changes (Hatzenbuehler, 2014; Krieger, 2014). For example, Sultana (2012) studied an incidence of arsenic poisoning in Bangladesh. The government and other partners installed deeper well systems to access groundwater, which was believed to be cleaner than surface water; unfortunately, groundwater in the region contained arsenic which led to arsenic poisoning. Despite public health education campaigns explaining the cause of arsenic poisoning, symptomatic individuals were already stigmatized, making it difficult to reverse 
social barriers to accessing water. Furthermore, Sultana (2012) found that some symptomatic individuals were less likely to seek treatment or speak up because they either feared stigmatization or could not afford treatment. These layered social, political, environmental, and economic scales all influenced the health status of individuals and how they accessed (or did not access) health services and water.

As we overlay scales of PEHD and structural stigma to pursue our research objectives, it is important to observe nuanced social barriers about local forest foods and medicines that have become cultural norms because they are difficult to reverse (Hatzenbeuhler \& Link, 2014). Raghavan et al. (2008) created a conceptual 'policy ecology' framework where stigma emerged in the mental healthcare system (Figure 1). 'Policy ecology' in the context of Raghavan et al.'s (2008) article refers to the 'ecology' of institutions, policymakers, and agencies that influence policy and subsequently determine an individual's clinical experience. Though a traditional PE framework is not applied or discussed in their article, Raghavan et al. (2008) described stigmatization of mental healthcare patients as a deeply embedded social issue that affects institutional and policy decision-making. Raghavan et al. (2008) suggested that singular interventions within hospital frameworks will not eliminate stigma around individuals with mental healthcare needs because mental health is stigmatized and a persistent cultural norm in larger social contexts. Stigmatization of homeless individuals in Rose's (2017) research and individuals with symptoms of arsenic poisoning in Sultana's (2012) study also appeared to be cultural norms that were difficult to overcome, creating barriers to healthcare or social services. While Raghavan et al. (2008) placed stigma in the social context of their policy ecology framework (Figure 1), we will be applying this framework to other external forces such as economic and political scales of power. We draw from examples such as Rose (2017), Sultana (2012), and Raghavan et al.'s (2008) policy ecology framework (Figure 1) to help us understand where structural stigmatization might exist in our study and its underlying effects on individuals' diet and health.

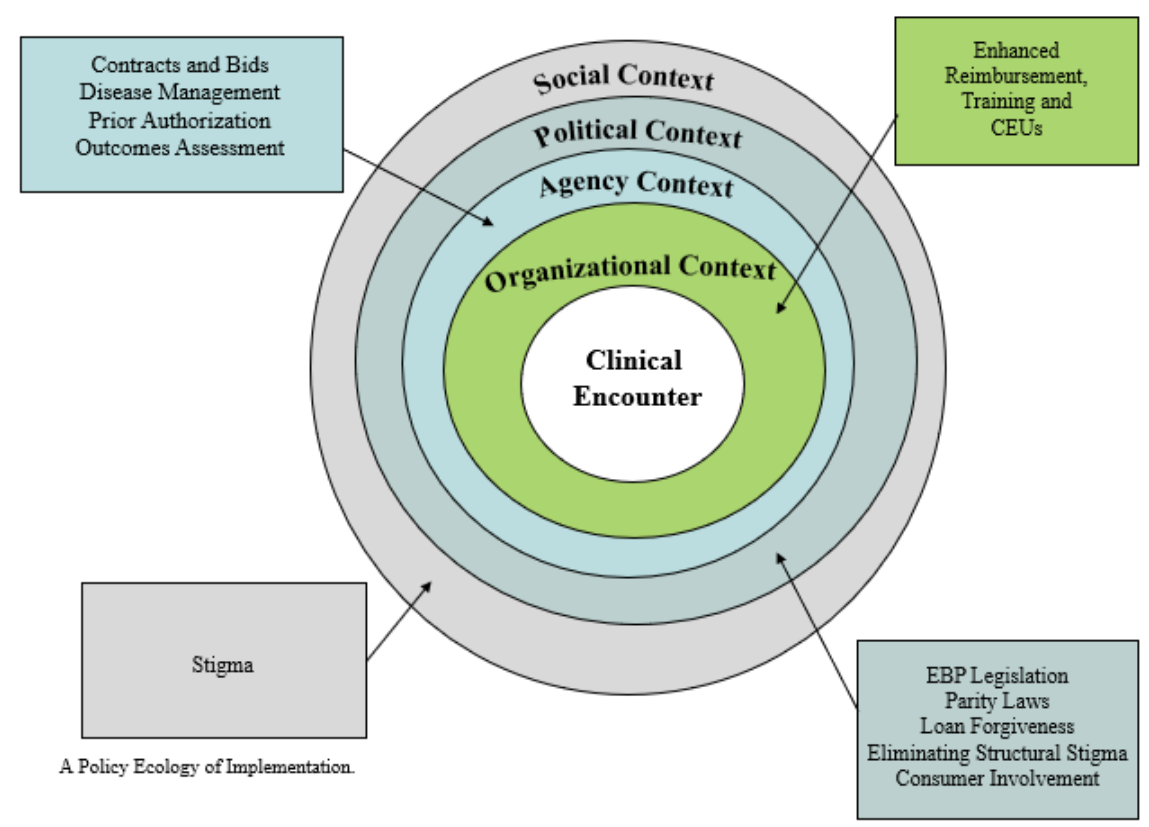

Figure 1: Raghavan et al.'s (2008) policy ecology framework displaying the multiple interacting policy, personnel, and institutional layers that affect and are affected by mental illness-related stigma. 


\section{Study site and social context}

Kédougou Region is in the southeastern corner of Senegal, bordering Guinea to the south and Mali to the east (figure 2). Kédouogu City is approximately $695 \mathrm{~km}$ southeast of Senegal's capital, Dakar, and $52 \mathrm{~km}$ south of the Niokolo-Koba National Park. Kédougou became its own region (like a state or province), encompassing $16,800 \mathrm{~km}^{2}$ in 2008 , with the small city of Kédougou as its capital. At the time of this research, about 151,000 people lived in Kédougou Region and Kédougou City had a population of about 37,000 (ANSD, 2015); currently, almost 200,000 people live in the region (ANSD, 2021). Although the population has more than doubled since 1976, about 79\% of the population still lives rurally (ANSD, 2015). Kédougou City has an active, daily open-air market where residents and people from across the region come to buy, sell, transport, and trade goods. Multiple languages and ethnic groups are present, including Pulaar, Bassari, Bedik, Dialonké, Mandinka, Bambara, Wolof, and Diaxanké. Apart from Bassari people, most ethnic groups in the region, including Pulaar people, are Muslim. Prior to French colonization, a large portion of Kédougou Region was part of the Fouta-Djallon Region which straddles the Senegal-Guinea border and is dominated by Pulaar speakers. Though Pulaar communities in the study region identify as Senegalese, many also identify as FoutaDjallon people. The influence of the border and relationships between communities on either side is complicated and nuanced; unfortunately, the influence of the border is outside of the scope of this study.

Kédougou Region has been characterized as tropical savannah, as it falls between Sudanian and Guinean ecological zones (USAID, CILSS, \& USGS, 2016). The region has distinct wet (June-September) and dry (October-May) seasons; peak rainfall is usually in August (roughly $300 \mathrm{~mm}$ ). Agroforestry is a common practice in the region; in addition to farming staple grains, individual households often cultivate gardens, a variety of fruit trees, and live fences (Papa et al., 2020). Staple grains include fonio, corn, millet, sorghum, and rice (Wood, 2018). Despite its low elevation, the region consists of foothills with higher plateaus bordering Guinea (image 1). Typically, the region receives an influx of people during the dry season, including from Nigeria, Niger, Berkina Faso, Mali, Mauritania, Guinea, and Guinea-Bissau, who come to work in large- and small-scale gold mines on the border of Mali. Many of these migrants return home during the rainy season because the mines become too dangerous (there is risk of flooding) and traveling on roads is difficult due to river crossings.

Important for the context of this study is that Pulaar people were historically migratory, cattle-herders (Azarya, 1993). Cattle ownership is still a large part of Pulaar identity in Kédougou Region because cows are a sign of wealth. Though livestock ownership (including goats and fowl) is regarded as a sign of wealth, particularly among older generations in the region, ideologies about wealth have begun to shift towards other material goods such as technology (e.g., solar panels, televisions, cell phones, vehicles). Informants in the study area live in clearings adjacent to forestland. At the time of this study, almost all informants or their families had access to small plots that they cultivated with non-motorized equipment for corn, rice, millet, sorghum, and fonio.

An important limitation of the study site is many individuals in the region know each other, are bloodrelatives, or relatives by marriage. This could potentially influence informants' responses because of shared perspectives or cultural values. Circumstantially, informants might share experiences, values, culture, and beliefs, despite having some distance between villages. However, similar belief systems and cultural values could be advantageous because informants still live in forested communities, primarily work as subsistence farmers, and are experiencing regional changes at a similar rate. Changes in the region include dietary, technological, urbanization, improved infrastructure, appearance of rural health clinics, and expanding gold mining industry. 

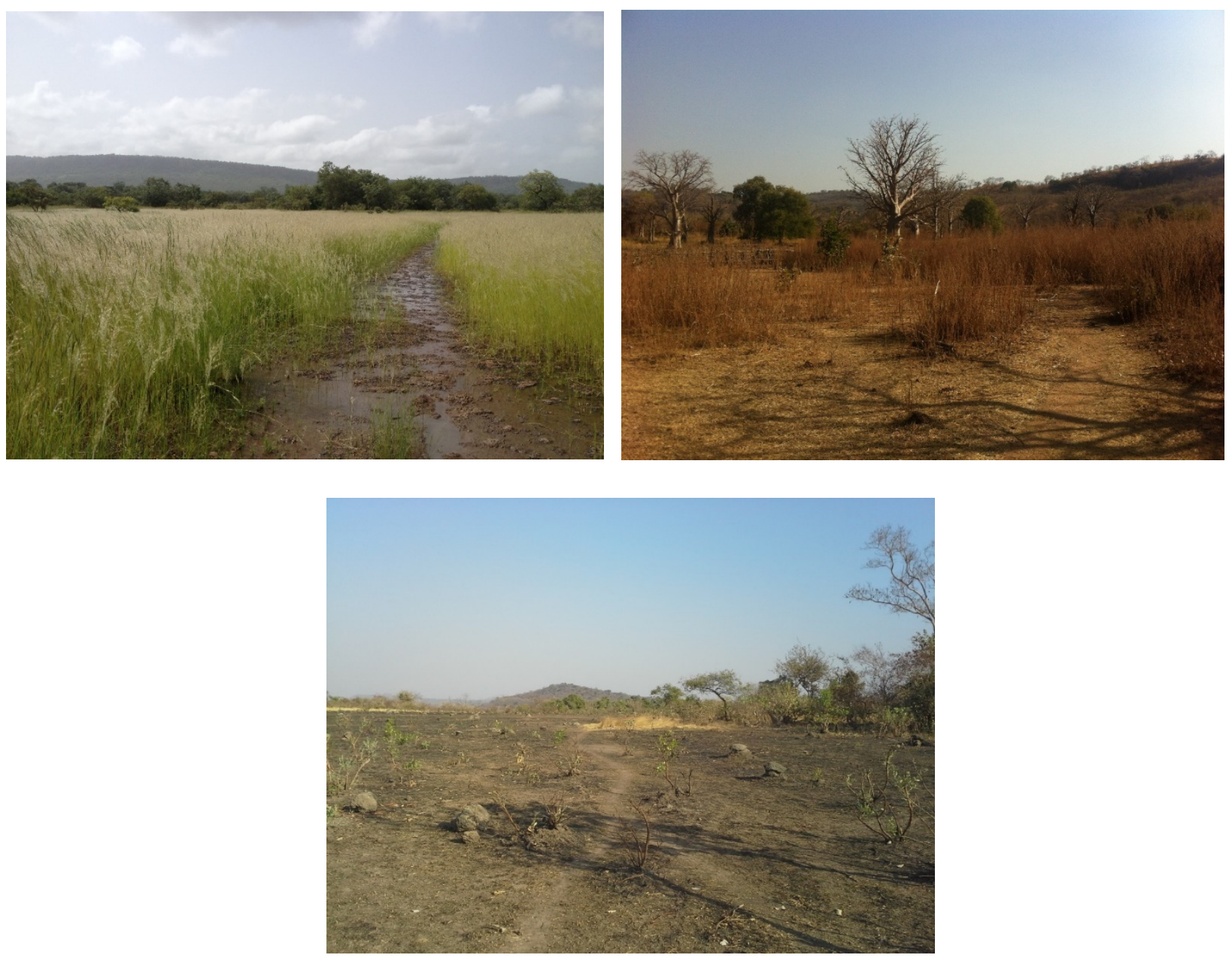

Image 1: Views from the main road traveling to study sites during rainy season (left), transition between seasons (right), and dry season (bottom).

\section{Methods}

To examine issues of access, nutrition, health, and stigmatization, we conducted research in rural, Pulaar villages. The lead author lived in Kédougou Region while serving as a Peace Corps Volunteer from September 2014 - November 2016. She carried out qualitative research, which included semi-structured interviews (25 total individuals), informant observation, and a food journal. These multiple sampling methods allowed for triangulation (Bernard, 2017). She lived in the village of Woulaba with a host family, which cultivated close social networks, offered her credibility with other key informants, and aided in snowball sampling (Bernard, 2017). Key informants were community members with whom she had rapport and conversations about diet and food. She interviewed some key informants on multiple occasions; key informants then provided suggestions for other villages where she would find knowledgeable informants, but with whom she did not have a preexisting relationship (Palinkas et al., 2016). She chose informants from different villages in the rural region of Kédougou to decrease the likelihood that individuals were blood relatives.

Of the total 25 informants (13 males, 12 females), the lead author interviewed 12 individuals one-on-one and 7 informants in joint interviews; 1 key informant also participated in 2 joint interviews. Interviews were audio-recorded, conducted in Pulaar, and lasted between 45-90 minutes. All informants lived in rural villages, except for two informants; although they currently lived in Kédougou City, they reflected on their rural past. 
Each informant was assigned a code made up of an identification number, letter indicating an age range ( $\mathrm{A}=$ 21-35, $\mathrm{B}=26-45, \mathrm{C}=46-55$, and $\mathrm{D}=55+$ ), and either ' $\mathrm{M}$ ' or ' $\mathrm{F}$ ' indicating a male or female informant. For example, '3AM', indicates the informant, identified as number 3, was a male between 21-35 years old.

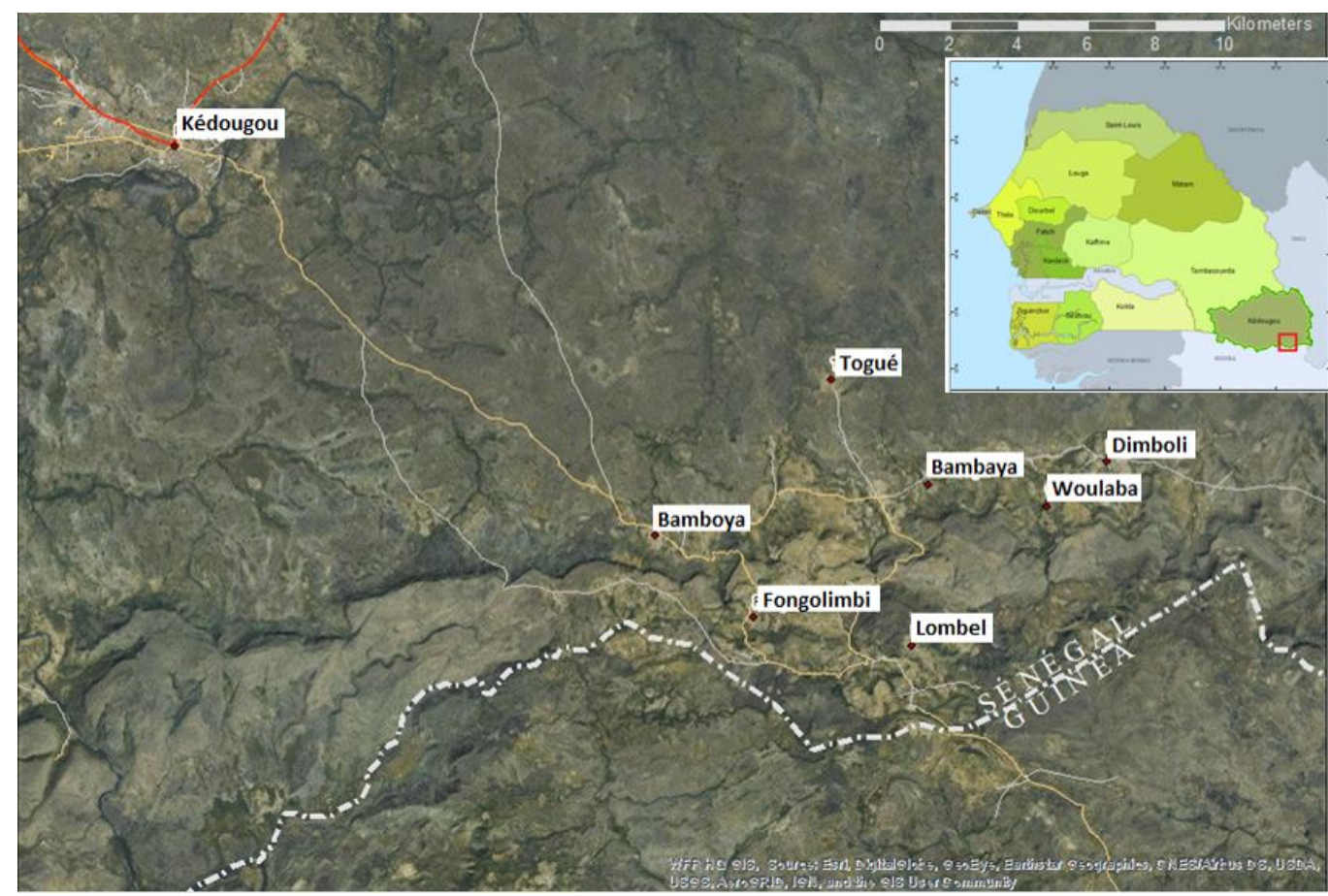

Figure 2: Kédougou Region location in Senegal, and study site locations.

In addition to semi-structured interviews, the lead author conducted participant observation, recording notes in a daily journal (Bernard, 2017). These notes contained thick description and observations of the study site, activities in which she participated with community members (e.g. farming, household chores, ceremonies, casual meals), cultural norms, household roles, food collection, and access to resources (Lincoln \& Guba, 1985). In a food journal, the lead author recorded 171 meals eaten with her host family and other rural households in the study region over 60 non-consecutive days (spanning March-October 2016). The food journal captured meals consumed both when food was scarce at the start of farming season (March-June) and when food was more available, during- and post-harvest season (July-October). While the food journal does not attempt to represent every family's diet in the region, it was helpful for triangulating informants' responses about dietary change and descriptions about diet.

The lead author transcribed interviews into English and organized transcribed data into common themes that arose throughout each interview. She placed themes into 'buckets', or larger themes. She additionally uploaded transcribed interviews into NVivo to create a code book, which aided in organizing buckets with informant quotations that supported thematic findings from transcribed interviews (Kvale \& Brinkmann, 2009).

As mentioned above, there are inherent limitations while conducting research with smaller sample sizes and in using snowball sampling in rural communities where there are strong social ties, but there are also studies that have noted forms of snowball or chain sampling can be most helpful in hard-to-reach populations (Sadler et al., 2010). Despite distance and isolation between villages, people in the region have broad social networks. Snowball sampling aided in identifying informants who were not blood relatives and were willing to talk to an individual outside of their community. The data gathered in this research is not meant to generalize Pulaar diets 
in Senegal, nor rural diets for the entire Kédougou Region. The purpose is to investigate a snapshot of diets in a rural area of Kédougou and to understand broader scales of influence on local diets.

\section{Perceptions about diets, access, and health in Kédougou}

\section{Diets in Kédougou}

Our first research objective was to understand diets in Kédougou and how they have changed in the region. To differentiate between current and historical diets, we use the Pulaar word, 'cosani' (cho-san-ee). Cosani refers to traditional or cultural Pulaar meals (cosani is also used as a word for culture or custom) that people reported their parents ate when they were children. We also use the term 'cosani medicine' to distinguish between local medicines (e.g. bark, roots, leaves) and globalized medicine (e.g. vaccines, antibiotics). Cosani medicine and foods overlap because locally collected forest foods are often considered medicine as well (e.g., shea butter).

There is limited historical data about diets in Kédougou Region, however, an ethnographic study from the late 1970s compared Pulaar, Bassari, and Boin (a Bassari group that adopted Pulaar culture) diets in the region (Lestrange, 1977). Out of 168 recorded meals, Lestrange found that meals contained 58\% rice, 35\% contained millet/fonio/corn, and 4\% potatoes. Unfortunately, Lestrange (1977) combined millet, fonio, and corn into one grain category, making comparison between cosani grains difficult. The 60-day food log from this study showed that meals contained $56 \%$ rice, $4 \%$ fonio or sorghum, $40 \%$ corn, and $5 \%$ potatoes (Table 1 ). Though the comparison between these two food journals is limited in scope, it is notable that rice might have been just as prevalent in 1977 as it was at the time of this study.

\begin{tabular}{lccc}
\hline Ingredients & $\begin{array}{c}\text { Cosani } \\
\text { food? }\end{array}$ & Total meals & $\begin{array}{c}\text { Included in \% } \\
\text { of total meals }\end{array}$ \\
\hline Rice & No & 79 & 56 \\
Corn & Yes & 57 & 40 \\
Fonio (D. exilis) or sorghum & Yes & 5 & 4 \\
Dairy (soured milk) & Yes & 12 & 9 \\
Leaf sauces: Amaranthus cruentus L., & Yes & 60 & 43 \\
Leptadenia hastate, Moringa oleifera, & & & \\
Manihot spp., and Adansonia digita L. & & 129 & 91 \\
Bouillon seasoning (cubes \& powder) & No & 12 & 9 \\
Sugar & No & 7 & 5 \\
Yams/tubers & Yes & 2 & .01 \\
Locust bean seeds (P. biglobosa) & Yes & 1 & $<0.01$ \\
Shea butter (V.paradoxa) & Yes & & \\
\hline
\end{tabular}

Table 1: Summary of lead author's 60-day food journal from rural Kédougou detailing 171 meals.

Informants in this study recalled that in the past, there were community-wide efforts to not only farm but also to collect cosani resources. Female informants older than fifty frequently mentioned that despite knowing how to collect and process cosani foods and medicines, they rarely taught younger generations. Lestrange's (1977) food journal and the interviews in this study revealed that typically the only added flavors in the past were: fermented locust bean seeds or 'ojji', salt, shea, soured milk, and honey. These were were used to flavor meals in the past.

Informants' descriptions of past and current diets, Lestrange's (1977) food journal, informant observations, and the lead author's food journal revealed a few notable dietary trends. One component largely 
absent is protein derived from meat; primary protein sources come from peanuts. During the 60-food log for this study, the lead author recorded three meals with beef and two with dried fish. Older informants revealed in interviews that more hunting occurred in the past which provided protein sources, but hunting is now illegal in the region. Most livestock were either saved for holidays and ceremonies (e.g. Ramadan, weddings) or sold for money. The addition of bouillon (i.e. MSG, commonly cubes \& powder), cheap oils (i.e. vegetable, palm, peanut oils), and white sugar gained popularity (Table 1). Notable for diets in Senegal is that salt is not a new delicacy; Senegal is one of two countries in West Africa (Ghana being the other), that produces salt (Mannar \& Yusufali, 2013). Most people in the region said they had regular access to the forest and were able to collect cosani foods and medicines; however, they perceived consumption of cosani was declining. In the following sections, we explore why shifts in diets might be taking place, and the potential health consequences of those shifts.

\section{Globalization trends}

Interviews and informant observation revealed a trend towards dietary homogenization across the country. Access to globalized foods products such as those mentioned in the previous section permeated every region of Senegal. The trends simultaneously put pressure on rural people to follow dietary trends and them away from cosani foods and medicines. When asked to describe dietary trends, one young informant responded,

From Dakar to [Kédougou], people eat all the same things. If the people in Dakar say, 'eat oil', then people here say, 'eat oil'... [N]ow we all eat oil for lunch. Maybe they'll eat a tiny bit of leaf sauce in the afternoon, and then oil at night (4MA).

Imported foods seemed to not only be a preference in the region, but they were also accepted socially and culturally. Furthermore, it was considered disrespectful not to offer guests the 'best' a family could afford. White rice or yellow corn frequently substituted cosani grains such as millet or fonio. Staple ingredients for savory sauces now always included bouillon, replacing ojji ${ }^{2}$, even in traditional dishes. Though shea trees were abundant in the region, people said they preferred cheap, imported oils. Younger female informants who were responsible for cooking admitted they were just following social trends. If they left bouillon out of their meals, they reported that their families complained the food lacked flavor or salt, and that their children refused to eat.

Now our vegetables (and sauces) are very different. Now it's Jumbo [bouillon], onions, vegetable and palm oil. There's no shea butter, people refuse to eat it... Now, our food tastes better. In the past, it was gross. But if I have shea butter, I'll add it in because I like it. (20FW)

Older informants said that some people consumed cosani foods daily, such as the leaves from trees and shrubs (like those in Table 1). However, they often remarked they now ate cosani in smaller quantities; in addition, younger generations only wanted to eat "welli (delicious) foods" and considered cosani to be bitter or tasteless. Even ojji, which, once combined with salt, has a similar flavor to bouillon seasoning, was not used as often as bouillon. Bouillon could simply be sprinkled into a sauce, while ojji required foraging, smoking, and fermenting. Several informants also claimed that people "could not stop" (7FD) eating imported foods now that they were accustomed to the taste. 4MA felt that there was no point in not eating the imported foods because they would "only be surviving", if they returned to eating cosani foods - in other words, they would be rejecting delicious, modern foods that everyone else was eating. What should be remembered is the convenience of these imported foods, which required less preparation and energy.

While the expansion of gold mining is not a primary focus of this research, its expansion sparked changes in local infrastructure, economics, regional job markets, and access to novel foods. International gold mining operations, typically Chinese- and Canadian-owned corporations (e.g. Sabodala, IAMGOLD), has pushed

\footnotetext{
${ }^{2}$ Ojji, or fermented locust bean seeds (P. biglobosa), were often combined with salt and dried hot peppers before being used as seasoning for sauces.
} 
capitalist behavior in the region. Informants said that if young men were not leaving the village to work as taxi drivers or sellers in Kédougou City, then they wanted to work seasonally in the mines. Subsistence farming did not offer a wage in exchange for hours spent, nor did it offer the slim promise of a large pay-off like working in the mines might. Hours spent in mines also meant fewer hours for subsistence farming or collecting cosani.

Gold mining companies in the region brought improved transportation and infrastructure, which further increased mobility and sped up the sale of globalized foods in the larger Kédougou markets. Advertisements throughout the country also displayed the now-familiar packaging of condiments such as bouillon, powdered milk made by Nestle, and cheap cooking oils. From Dakar to rural corners of the country, large billboards proudly displayed Senegalese women wearing expensive West African fabrics, holding traditional Senegalese dishes with the words 'Doli' or 'Adja' (bouillon) printed in large letters above their heads. Other advertisements displayed items such as brand-new homes, in addition to well-dressed women and bouillon seasonings (Image 2). These advertisements loudly demonstrated the perception that imported foods were a cultural norm, and even an expectation.

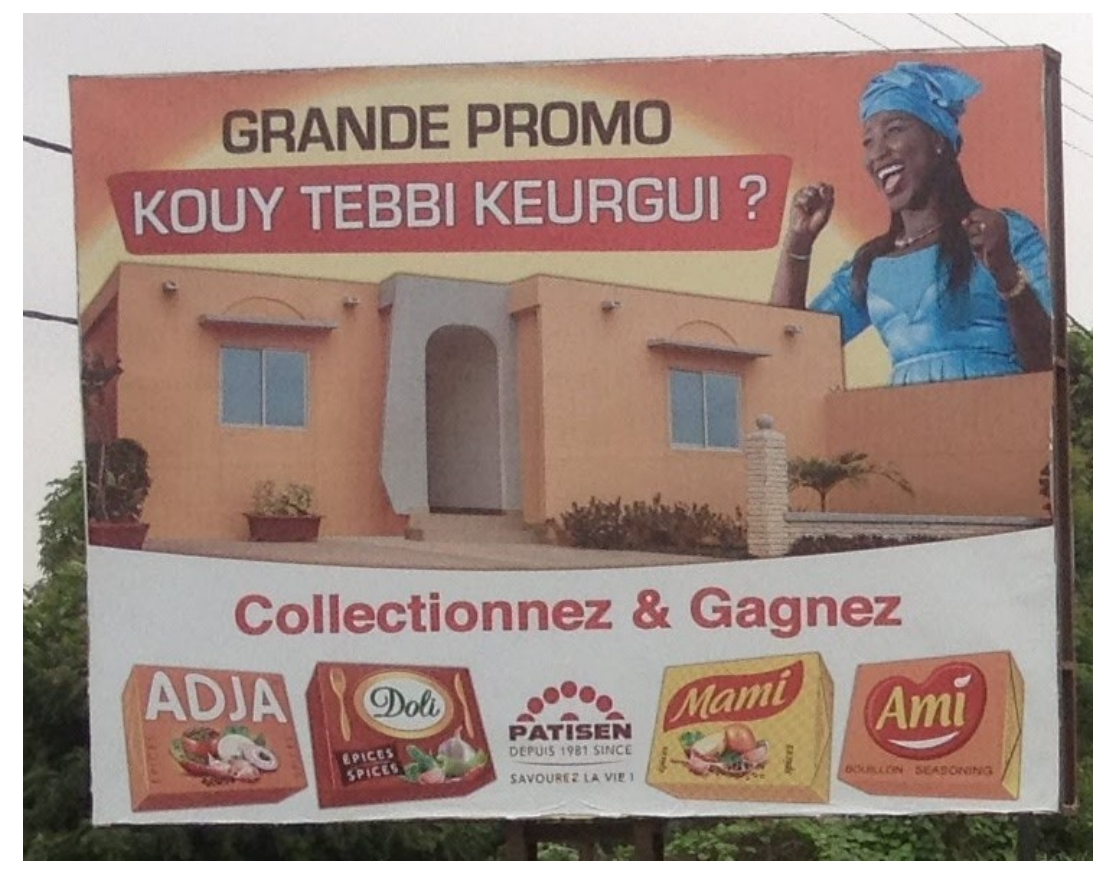

Image 2: Billboard advertising bouillon, a common sight throughout Senegal.

\section{Markets and changing access}

Globalization was prevalent at local scales through informants' abilities to access and participate in markets. The concepts of limited access and increased access are intertwined, connected through accessing forest foods and imported foods. The expanding open-air market in Kédougou city presented commerce opportunities, however, it also drew local, subsistence resources away from rural villagers. The city market offered a venue with richer, urban consumers, and informants perceived that rural weekly markets were shrinking. People in the region must purchase imported foods, modern medicines, and other items from the city market where they were more readily available. 4MA, who operated a small shop and lived about $30 \mathrm{~km}$ from Kédougou City remarked, 
There's nowhere for [people] to buy things. They don't say, 'Hang on, I'm going to go buy carrots, cabbage, lettuce'... [T]here is nothing at the boutiques. It's just oil, bouillon seasoning, onions, mustard, and vinegar. That's it. And rice.

Boutiques in rural villages were small structures that typically did not have electricity, so refrigeration was impossible (Image 3). Even if rural boutiques sold vegetables, meat, and other perishable goods, there was no guarantee that they could be sold because rural people regularly could not afford them.

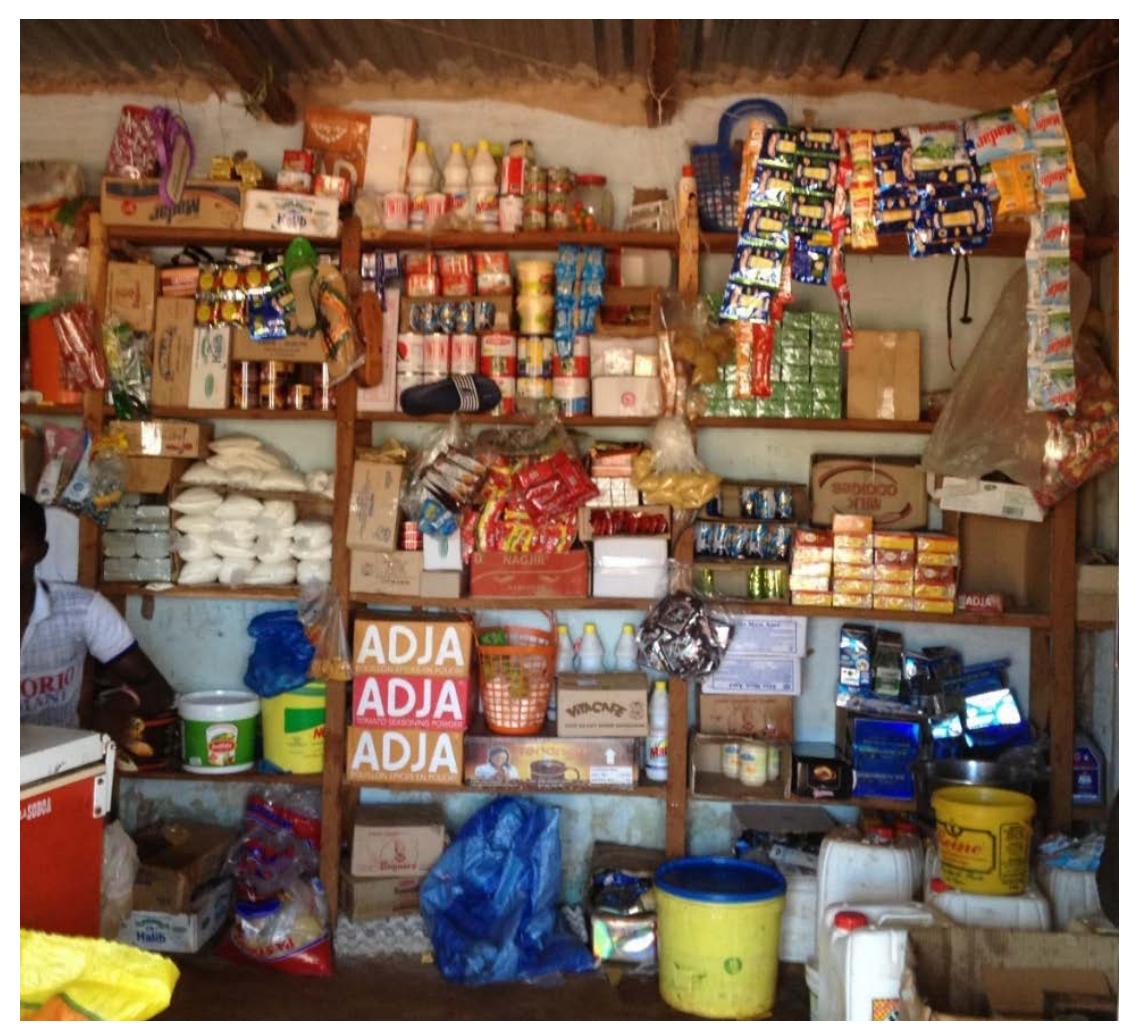

Image 3: Boutique - displaying bouillon seasoning, powdered milk, bags of white sugar, cooking oils and other goods.

When rural boutiques or weekly markets sold cosani foods, informants often complained that it was too expensive. For example, yogurt ${ }^{3}$ was a cosani food that was once regularly accessible and offered as a gift between community members. During an interview, one informant simply stated,

Work changed. Early on, we had a lot of soured milk... Now, the women work [in] the [community] garden... Now you don't milk cows as often and soured milk is expensive... It's changed forever. (13MB)

While purchasing imported food instead of collecting forest foods saved cooking time, there was new pressure to generate income. This was particularly difficult for women because male heads of households usually

\footnotetext{
${ }^{3}$ Kossam - raw, fermented cow's milk.
} 
controlled income, yet women were responsible for providing food and cooking duties. One young mother explained in hurried tones,

If you work until you have your money, then your heart rests. If you don't have it, you are running... No one sits—-not a woman, not a man, not a child...A brand-new baby is looking for money.... Now is the money generation. (14FC)

An older informant commented that cosani foods, including game meat (e.g. porcupine, antelope), were at one time their "savings account" (3FD), but they have since lost that security since purchasing more goods at the market. 8FD said she knew how to make cosani and it was accessible, pointing to shea and African locust bean trees nearby. However, instead of consuming cosani foods, she and her family would sell them to buy imported foods.

I pick [baobab leaves] and I pound it into powder. I give it to the children [to sell in Kédougou] and they buy me... Jumbo [bouillon] (8FD).

Kédougou's expanding gold mines and growing urban population additionally facilitated the selling of cosani foods. For example, there was a noticeable peak in market activity during hot season (March-May) when mangoes were ripe. Women collected mangoes from their villages and sold them in the city, typically to people looking to re-sell them in the gold mines for an even higher price. Rural people continued to consume mangoes in their villages, but high demand for the fruits elsewhere pushed people to collect larger quantities to sell.

\section{Health and disease}

As discussed previously, cosani medicines and cosani foods often overlap because some foods are attributed with medicinal properties. Modern medicines were frequently referred to as 'toubab medicine' or white person medicine. Most informants reported that people in the region stopped using cosani medicines because 'white person medicine' was now available. When asked where these medicines came from, the response was often simply, 'the government.' The government could refer to government programs or other agencies such as nonprofit organizations. For example, 3FD explained that people stopped eating cosani because,

[The government] said, 'Change.' They brought medicines. [The medicines] work... [The people] got better, which is why we stopped our traditions. Let's follow what white people (toubabs) are doing. (3FD)

Regardless of age, informants perceived that although there was more food available today, people were healthier in the past, before they started eating imported foods and slowed consumption of cosani foods and medicines. Informants believed that bouillon caused limbs to swell as people aged and white rice caused people to become fatigued. Informants additionally reported that people were developing 'new' diseases, such as hypertension and type 2 diabetes, since diets shifted. They said that people were dying younger, and that children were weaker and shorter than they were in the past. 1MD commented, "Now, thanks to God, there's a little more food but there is a lot of chronic sickness." 10MC reported that their house was full of "children with chronic illnesses", despite having access to their own farmland and urban markets.

Although most informants lacked formal education about health and nutrition, they believed that these new health problems were a direct result of substituting cosani foods and medicines for imported foods and modern medicines. A common sentiment was that imported foods contained nothing of nutritional value. 24MD scoffed, "there is nothing in [imported foods]", and "[those foods] do not offer health." Older informants felt 
that while modern medicine temporarily abated health issues, they did not provide preventative measures that cosani medicines offered. However, most informants reported that with increased access to hospitals and rural clinics, they sought advice from a trained doctor or nurse, vaccinations, and other pharmaceuticals instead of seeking medicinal advice within their communities.

A young community health worker (18MB) said that there was "less suffering" now because free government programs offered children under the age of five malaria vaccinations and vitamin supplements. Older informants, on the other hand, claimed that modern medicine could not treat some illnesses that rural health clinics knew nothing about (e.g. evil spirits). An informant who claimed to be 100 years old the day of his interview, explained,

In the past, people were healthier... But now, it's only children who are dying. There is a lot of illness and a lot of death (25MD).

The perception of a higher prevalence of death was repeated throughout interviews. Older informants felt the health of younger generations would continue to suffer if they did not return to a diet that incorporated more cosani foods. Both younger and older informants, however, expressed there were tradeoffs between having more to eat and consuming nutritious, cosani foods. Informants primarily said people did not 'suffer' because they were rarely hungry now that imported white rice could be purchased, but now people were developing NCDs.

\section{Stigmatization of cosani}

New foods were difficult to avoid due to social expectations. Throughout interviews and informal conversations, stigma emerged around cosani foods and medicines. Informants also made contradictory statements about cosani. Informants said commonly eaten imported foods lacked any nutritional value, yet their consumption was consistently expected at ceremonies, holidays, and everyday meals. It is possible that this expectation evolved from social pressures to follow new cultural norms. There was a sense of internal community stigma in the study region. People teased each other about engaging with cosani medicines or consuming cosani foods, despite admitting that they felt cosani was healthier. Even respected members of rural communities felt that though cosani was their preference, new cultural norms stopped them from suggesting that it should be eaten within their own families. During an interview 9FD admitted,

Personally, I do not like it and do not eat Jumbo (bouillon seasoning) or Mami Tamate (packaged tomato paste), but if you go to events (weddings, etc.) you are obligated to eat them because those products are mixed in and people expect them in their sauces.

Older informants, more familiar with cosani foods, lamented the obligatory imported flavoring in traditional dishes, and claimed that imported foods represented the preferences of younger people. However, older and younger informants said that food tastes better now than it used to in the past, and people 'suffer less' because grains can be purchased when their personal stores are low.

Internal and external stigma appeared to create a positive feedback cycle when people compared historical diets to perceived dietary changes. For example, informants felt that 'white person medicines' did not offer the preventative care that cosani medicines provided, but non-cosani medicines were generally accepted as effective and people sought them out. When asked where they went if a family member fell ill, informants responded without hesitation, 'to the hospital' or rural clinic. Messaging from hospital visits, conversations with local health workers who grew up rural villages, and conversations between rural villagers reinforced the notion that cosani medicines should not be used. 
During casual conversations, community members would lower their voices when they spoke about others who continued to search for either cosani medicines or hunted for game in the forest. People explained that in addition to tree and shrub species, game was also considered cosani. They said that at one time, game was a larger source of protein for people, especially in rural areas. Much like the use of cosani, game was a taboo subject because it was often associated with being poor and connected to the Ebola virus outbreak in bordering countries in 2014 (CDC 2019). Although the impacts of Ebola on access to cosani was not explored in this research, frequent radio announcements at the time warned people not to eat any wild animals because they could be exposed to Ebola. Public health messaging from governmental and media sources created fear about contracting Ebola and further heightened stigma about what kinds of foods should be eaten.

Additionally, city health workers further deepened stigma associated with cosani foods and medicines by routinely making appearances in rural communities to perform hand-washing trainings and to inform people that they should not eat forest foods because they were dirty and would make people sick. These health workers usually arrived in vehicles from urban areas, and were generally formally educated and dressed nicely. They typically only spoke French or Wolof, making communication with rural Pulaar-speaking villagers difficult. People in villages became visibly uncomfortable when health workers explained slowly, and at length, how villagers should wash their hands with soap. Furthermore, clinicians advised people to always come to the rural health clinic if they were sick, and to not attempt to self-treat or treat others with cosani medicines. The apparent discomfort that villagers experienced during these interactions emphasized both the stigmatization of cosani foods and medicines in the study region and the importance of adapting to globalized public health ideologies.

\section{Discussion}

\section{Dietary and health perceptions}

Informants in the study region believed that increased consumption of globalized foods was leading to decreased consumption of cosani. They described a delocalization of diets - increased consumption of bouillon, cheap cooking oils, white sugar, white rice - and believed this shift contributed to development of NCDs. Although consumption of globalized food products has spread unevenly across Senegal, our finding that there is a trend towards globalized diets in the study region, is similar to other research that examined dietary substitution and delocalization (Nichols, 2015; Popkin, 2017; Richmond et al., 2005; Yates-Doerr, 2015). Different in our study, however, is that informants claimed to still have physical access to perceived healthier cosani foods and medicines. Physical accessibility of cosani indicated there could be other factors influencing dietary decisions. Although consumption can be quantitively estimated from economic trends, individual- and family-scale dietary decision-making is more complex and nuanced.

Cosani foods (Table 1) might seem insignificant in that they add little caloric substance to a meal (e.g. leaves in sauces); however, there is evidence that local forest foods provide essential micronutrients throughout Africa (Arimond et al., 2018; Buchmann et al. 2010). For example, leaves of the shrub, Combretum micranthum

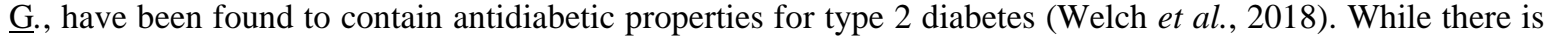
limited data about NCD development in Kédougou Region, West Africa has experienced a rise in NCDs in recent years, which makes understanding drivers of NCD development more urgent. Rates of hypertension been rising in West Africa since 1980 and the region faces the highest projected increase of type 2 diabetes in the world (Bosu, 2015; Naik \& Kaneda, 2015; Rafei, 2014). Interesting in our study was not just a partial shift towards a globalized diet, but rather our finding that consumption of cosani was becoming othered, despite informants' knowledge of its nutritional value.

Informants in our research drew a connection between 'new' foods and 'new' illnesses. They continued to weigh up the imperfect tradeoffs of labor-intensive cosani from their past, and the convenient foods of today. Imported foods could be purchased anywhere, larger markets were becoming available, and more incomeearning opportunities were emerging. For rural Kédougou, these socioeconomic changes mean that food can be purchased during the difficult months between farming seasons when staple crops become scarce. Vaccinations, 
malaria treatments, and rural clinics offer solutions for treatable illnesses. Despite these advancements for the region, Kédougou could become vulnerable when global markets inevitably became unstable (Rosen \& Shapouri, 2008; Scoones et al., 2019). Kédougou residents should not have to choose between what is customary and local, and what is new and convenient. External forces - the current economic, social, and political boundaries, offer or prevent balanced access to some of these resources.

\section{Intersection of physical access and social barriers}

Our findings led us to a supplementary lens for 'limited access' (Peluso, 1996), within a PEHD framework, that builds on limited social access to- or barriers to- cultural acceptability of local, traditional forest foods and medicines. Social barriers primarily appeared as subtle stigma throughout our research. Stigmatization of cosani was reflected in community dynamics, broader regional contexts, and further reinforced by public health messaging. Cultural pressure and expectations to provide the best meals for guests and to take family members to western-trained medical clinics when ill, manifested the unintended consequence of structural stigmatization (Hatzenbuehler \& Link, 2014; Ragahavan et al., 2008). PEHD is a small sub-field of PE and the social barrier of stigma has not been fully analyzed in the PE and PEHD literature; however, some research has explored health differences between stigmatized groups and non-stigmatized groups, noting that non-stigmatized groups tended to be healthier (Hatzenbuehler \& Link, 2014; Rose, 2017; Singer et al., 2017). We found that both external and internal forces encouraged stigmatization of cosani foods and medicines. Community health worker ideologies paralleled messaging from rural health clinics and public media; these messages conflicted with expertise regarding cosani foods and medicines.

We modified Raghavan et al.'s (2008) policy ecology framework to display the various scales of power influencing perceptions about health, disease, and forest use that emerged in our study (Figure 3). Raghavan et al.'s (2008) original framework broke down the 'ecology' of health clinics and identified stigmatization embedded in the social context of the mental health care system.

Our modified framework (Figure 3) is a simple one, intended to be reproduced in future analyses. The modified framework displays stigmatization embedded within the social context as in Raghavan et al. (2008); however, we placed individual perceptions of health, disease, and forest use at the center. Individual perceptions replace 'Clinical Encounter' in Raghavan et al.'s (2008) framework because this is where individual perceptions, beliefs, and behaviors around cosani are formed. These beliefs are reinforced by internal and external forces. Internal forces are the personal relationships between community members (e.g. community expectations) and personal experiences with cosani. External forces include the political, economic, and ecological scales of power; other external forces include public health messaging. Like Raghavan et al. (2008), the social context at the local level appeared to be where stigmas manifested in our study. We placed social context in the interior of our modified framework to demonstrate the community scale belief systems that influence knowledge about, and cultivation of cosani.

Beyond the popularity of imported foods and social pressure to visit health clinics, informants faced additional forces that influenced dietary decisions. External political and economic forces such as land management, hunting, and health policies also reached local scales and influenced social norms about cosani. Health workers were dispatched during and after the Ebola outbreak to rural communities, many of whom repeated messages that cosani medicines were ineffective or that forest foods, such as game, could carry the Ebola virus (CDC, 2019). These messages came from the urban and educated, well-dressed government or nonprofit employees who arrived unannounced in vehicles. Combined with a preference for globalized foods, these messages reinforced stigmatization of cosani. This stigma was a new layer to social barriers around cosani and a perceived decline in collection of cosani led informants to believe that it was also less accessible. Our findings suggest the tight-knit, insular nature of the study site protected beliefs and knowledge about the benefits of cosani, but these beliefs were not impermeable to globalized ideological trends. 

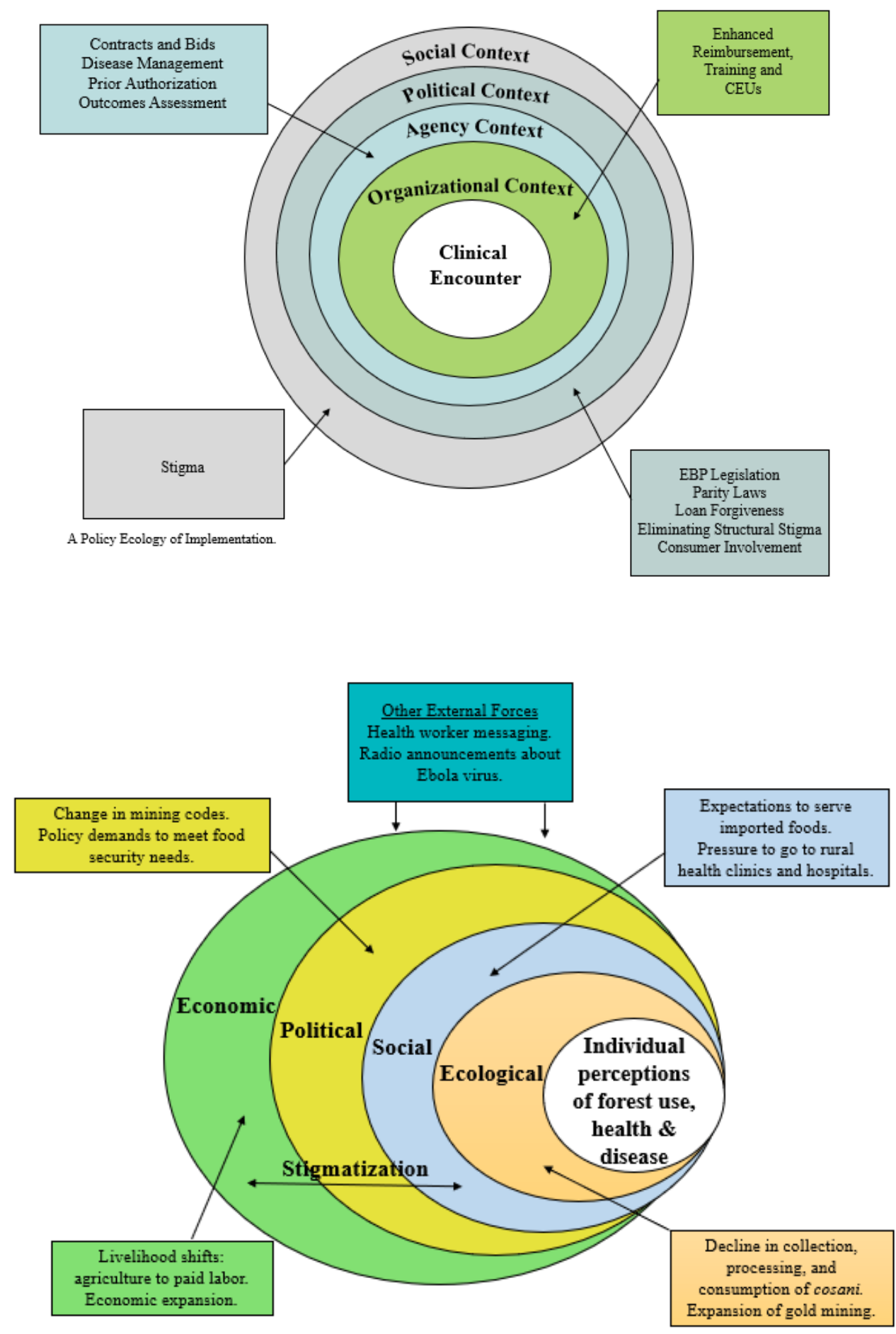

Figure 3: Raghavan et al.'s (2008) Policy Ecology framework (top) and our modified framework: Political Ecology of Health and Disease highlighting perceptions of forest use, health, and disease (bottom). 


\section{Conclusion}

Rural populations in Kédougou, Senegal not only risk disease development in the future, but also risk losing generations of knowledge about local foods and forest stewardship if current globalized dietary and health ideologies continue to be valued over local ideologies (Menzies, 2006; Popkin, 2017). Informants struggled with balancing a desire for 'delicious' imported foods and 'healthier' cosani foods. Rejecting cosani and substituting it for imported foods and medicines had become normalized, which produced negative perceptions about declining health. Normalizing globalized foods and health ideologies created a positive feedback loop which led to stigmatizing cosani. What was not stated during interviews, was that cosani is a word applied to Pulaar historical and cultural norms that are often associated with a geography of the poor, uneducated, and rural communities without technological advances. In other words, cosani food and medicine is representative of the rural farmers - the powerless.

Our article ties together examples from PEHD literature and other work that explores the consequences of stigma and structural stigmatization (Hatzenbuehler \& Link, 2014; Nichols, 2015; Sultana, 2012; Rose, 2017; Yates-Doerr, 2015). Our modified framework (Figure 3) adds to PEHD literature by highlighting stigmatization as a barrier across scales of power that ultimately influences individual perceptions and use of local forest foods and medicines in the context of Kédougou. Like Ogden et al. (2013), we found that by digging deeper into the individual health and disease perceptions of informants in the region and recognizing the place-specific and culture-specific dietary preferences, nuanced social barriers could be uncovered through individual dietary histories.

Health and disease information in our study site was only disseminated through educated actors with formal training. These individuals were trained with a globalized standard of medicine that contradicted or denigrated local knowledge. Even though informants observed new health and disease trends that they connected to decreasing consumption of cosani and increased consumption of imported foods, there appeared to be tension and contradiction around these shifts. Formal health education was valued by informants, but it also represented a powerful barrier to accessing cosani medicines from the forest. Informants were judged by other community members for using cosani forest remedies, or if they did not choose to take themselves or family members to see a formally trained medical professional.

Because every context is equipped with interwoven social, economic, political, and ecological scales, it would be unrealistic to expect that implementing large-scale policy changes or educational changes would lead directly to improved health (Neely \& Nading, 2017). Furthermore, even changes at varying scales of influence cannot eliminate widespread stigmas that have become cultural norms (Raghavan et al., 2008). Future research should examine barriers to localized education about nutrition (particularly about locally collected foods) and advocacy for continued stewardship of forests in Kédougou to maintain access to nutrient-rich cosani foods (Detraz, 2017; Jones et al., 2014). Another important aspect of access that could be further explored is changing household roles. Women traditionally collect and process local forest foods in addition to cooking meals. It is possible that women could be disproportionately affected by NCD-development; however, women in our research were increasingly more involved with selling forest foods, which offered a new source of income.

Whether it is pressure, preference, or increased access to globalized foods influencing dietary decisionmaking, it is important for working knowledge of edible and medicinal forest species to be maintained and that stigma is reduced (Trosper \& Parrotta, 2012). Stigmatization of local forest foods and medicines might not only influence disease development in Kédougou, but could also influence forest stewardship efforts, while increasing dependence on imported products. Our findings suggest that social access barriers, such as stigma, may have a strong bearing on diet and healthcare decision-making in small communities, even in circumstances where local foods and medicines are physically accessible. Reducing stigma would decrease social barriers to accessing freely collectable and nutritionally valuable foods and medicines, which is critical in a globalized world where access to healthcare or health information is unequal. 


\section{References}

Arimond, M., Vitta, B. S., Martin-Prével, Y., Moursi, M., \& Dewey, K. G. (2018). Local foods can meet micronutrient needs for women in urban Burkina Faso, but only if rarely consumed micronutrient-dense foods are included in daily diets: A linear programming exercise. Maternal \& Child Nutrition, 14(1), e12461. https://doi.org/10.1111/mcn.12461

Azarya, V. (1993). Sedentarization and ethnic identity among the Fulbe: A comparative view. In P. K. Eguchi \& V. Azarya (Eds.), Unity and diversity of a people: the search for Fulbe identity (pp. 35-60). Senri Ethnological Studies.

Bennett, A., Ravikumar, A., \& Paltán, H. (2018). The political ecology of oil palm company-community partnerships in the Peruvian Amazon: Deforestation consequences of the privatization of rural development. World Development, 109, 29-41.

Bernard, H. R. (2017). Research methods in anthropology: Qualitative and quantitative approaches. Rowman \& Littlefield.

Blaikie, P.M. (1985). The political economy of soil erosion in developing countries. Longman.

Bosu, W. K. (2015). An overview of the nutrition transition in West Africa: implications for non-communicable diseases. Proceedings of the Nutrition Society, 74(4), 466-477. https://doi.org/10.1017/S0029665114001669

Connolly, C. (2017). "Bird cages and boiling pots for potential diseases": Contested ecologies of urban 'Swiftlet farming' in George Town, Malaysia. Journal of Political Ecology, 24(1), 24-43. https://doi.org/10.2458/v24i1.20780

Connolly, C., Kotsila, P., \& D'Alisa, G. (2017). Tracing narratives and perceptions in the political ecologies of health and disease. Journal of Political Ecology, 24(1), 1-10. https://doi.org/10.2458/v24i1.20778

Daffé, L. (2012). Gold rush in Kédougou, Senegal: Protecting migrants and local communities. Global Eye on Human Trafficking (IOM). https://publications.iom.int/system/files/pdf/globaleyeissue11_29feb2012.pdf

Detraz, N. (2017). Gender and the environment. Wiley.

Dorin, A., \& Welsh, L. (2017). Senegal: A brief overview of mining in Senegal. Mondaq: The Mayer Brown Practices. Retrieved from http://www.mondaq.com/x/604334/Mining/A+Brief+Overview+Of+Mining+In+Senegal.

Fall, A. (2015). Towards a new Mining Code for Senegal. American Bar Association. Dakar, Senegal: GENI \& KEBE, SCP de A'vocats. Retrieved from https://www.americanbar.org/content/dam/aba/events/international_law/2015/06/Africa\%20Forum/Mi ning2.authcheckdam.pdf.

Jones, A. D., Shrinivas, A., \& Bezner-Kerr, R. (2014). Farm production diversity is associated with greater household dietary diversity in Malawi: Findings from nationally representative data. Food Policy, 46, 112.

Hatzenbuehler, M. L. (2014). Structural stigma and the health of lesbian, gay, and bisexual populations. Current Directions in Psychological Science, 23(2), 127-132.

Hatzenbuehler, M. L., \& Link, B. G. (2014). Introduction to the special issue on structural stigma and health. Social Science \& Medicine 103, 1-6.

Kennedy, G., Nantel, G., Shetty, P. (Eds.) (2004). Globalization of food systems in developing countries: impact on food security and nutrition. FAO Food and Nutrition Paper, 83.

Köpke, S. (2021). Reinvigorating a political ecology of the global agri-food system. Fennia 199(1), 89-103. https://doi.org/10.11143/fennia.99209

King, B. (2010). Political ecologies of health. Progress in Human Geography, 34(1), 38-55.

Krieger N. (2001). Theories for social epidemiology in the 21st century: An ecosocial perspective. International Journal of Epidemiology, 30(4), 668-677. https://doi.org/10.1093/ije/30.4.668

Kvale, S., \& Brinkmann, S. (2009). Interviews: Learning the craft of qualitative research interviewing. Sage. 
Leatherman, T. (2005). A space of vulnerability in poverty and health: Political-ecology and biocultural analysis. Ethos, 33(1), 46-70.

L'Agence Nationale de la Statistique (ANSD) et de la Demographie. (2021). Retrieved from http://www.ansd.sn/index.php?option=com_regions\&view=region\&id=9

L'Agence Nationale de la Statistique (ANSD) et de la Demographie. (2015). Situation economique et sociale regionale. Ministre de l'Economie, des Finances et du Plan, Republique du Senegal 1-13. Retrieved from https://www.ansd.sn/ressources/ses/SES-Kédougou-2013.pdf

L'Agence Nationale de la Statistique (ANSD) et de la Demographie and ICF International. (2012). 2010-11 Senegal Demographic and Health and Multiple Indicators Survey: key findings. Calverton, Maryland, USA: ANSD and ICF International. Retrieved from https://dhsprogram.com/pubs/pdf/FR258/FR258_English.pdf

de Lestrange, M. T. (1977). Alimentation et anthropobiologie: Données concernant les Bassari, Boin et Peul de la Region De Kédougou, Senegal Oriental. Bulletins et Mémoires de la Société d'Anthropologie de Paris, 4-4, 371-381.

Lincoln, Y. S., \& Guba, E. G. (1985). Naturalistic inquiry. Sage.

Mannar, V., \& Yusufali, R. (2013). Salt production and trade in Africa. IDD Newsletter, 41, 19-20. Retrieved from https://ign.org/newsletter/idd_nov13_salt_trade.pdf

Mayer, J. D. (1996). The political ecology of disease as one new focus for medical geography. Progress in Human Geography, 20(4), 441-456.

Menzies, C. R. (Ed.). (2006). Traditional ecological knowledge and natural resource management. University of Nebraska Press.

Neely, A. H., \& Nading, A. M. (2017). Global health from the outside: The promise of place-based research. Health \& Place, 45, 55-63.

Nichols, C. E. (2015). Shifting production/shifting consumption: A political ecology of health perceptions in Kumaon, India. Geoforum, 64, 182-191.

Nichols, C. (2017). Millets, milk and maggi: contested processes of the nutrition transition in rural India. Agriculture and Human Values, 34(4), 871-885.

Olayiwola, K., Soyibo, A., \& Atinmo, T. (2004). Impact of globalization on food consumption, health and nutrition in Nigeria. In Kennedy, G, Nantel, G., \& Shetty, P. (Eds.), Globalization of food systems in developing countries: Impact on food security and nutrition. FAO Food Nutrition Papers 83.

Palinkas, L. A., Horwitz, S. M., Green, C. A., Wisdom, J. P., Duan, N., \& Hoagwood, K. (2015). Purposeful sampling for qualitative data collection and analysis in mixed method implementation research. Administration and Policy in Mental Health and Mental Health Services Research, 42(5), 533544.

Papa, C., Nzokou, P., \& Mbow, C. (2020). Farmer livelihood strategies and attitudes in response to climate change in agroforestry systems in Kédougou, Senegal. Environmental Management, 66, 218-231. https://doi.org/10.1007/s00267-020-01302-8

Pelto, G. H., \& Pelto, P. J. (1983). Diet and delocalization: dietary changes since 1750. The Journal of Interdisciplinary History, 14(2), 507-528.

Peluso, N. L. (1996). Fruit trees and family trees in an anthropogenic forest: Ethics of access, property zones, and environmental change in Indonesia. Comparative Studies in Society and History, 38(3), 510-548.

Persaud, A. W., Telmer, K. H., Costa, M., \& Moore, M. L. (2017). Artisanal and small-scale gold mining in Senegal: livelihoods, customary authority, and formalization. Society \& Natural Resources, 30(8), 980993.

Popkin, B. M. (2017). Relationship between shifts in food system dynamics and acceleration of the global nutrition transition. Nutrition Reviews, 75(2), 73-82. https://doi.org/10.1093/nutrit/nuw064 
Rafei, L., \& Tabary, M. E. (2014). Africa's urban population growth: trends and projections. The Data Blog. The World Bank. Retrieved from https://blogs.worldbank.org/opendata/africa-s-urban-populationgrowth-trends-and-projections.

Raghavan, R., Bright, C. L., \& Shadoin, A. L. (2008). Toward a policy ecology of implementation of evidencebased practices in public mental health settings. Implementation Science, 3(1), 1-9. https://doi.org/10.1186/1748-5908-3-26

Remans, R., Wood, S. A., Saha, N., Anderman, T. L., \& DeFries, R. S. (2014). Measuring nutritional diversity of national food supplies. Global Food Security, 3(3-4), 174-182.

Resnick, D. (2013). Personalistic policy-making in a vibrant democracy: Senegal's fragmented response to the 2007/08 food price crisis (WIDER Working Paper 2013/015). United Nations University.

Ribot, J. C., \& Peluso, N. L. (2003). A theory of access. Rural Sociology, 68(2), 153-181.

Richmond, C., Elliott, S. J., Matthews, R., \& Elliott, B. (2005). The political ecology of health: perceptions of environment, economy, health and well-being among 'Namgis First Nation. Health \& Place, 11(4), 349365.

Rose, J. (2017). Cleansing public nature: landscapes of homelessness, health, and displacement. Journal of Political Ecology, 24(1), 11-23. https://doi.org/10.2458/v24i1.20779

Rosen, S. L., \& Shapouri, S. (2008). Rising food prices intensify food insecurity in developing countries. USDA Economic Research Service.

Sadler, G. R., Lee, H. C., Lim, R. S. H., \& Fullerton, J. (2010). Recruitment of hard-to-reach population subgroups via adaptations of the snowball sampling strategy. Nursing \& Health Sciences, 12(3), 369374.

Scoones, I., Smalley, R., Hall, R., \& Tsikata, D. (2019). Narratives of scarcity: Framing the global land rush. Geoforum, 101, 231-241. https://doi.org/10.1016/j.geoforum.2018.06.006

Shetty, P. (2003). Impact of globalisation on food and agriculture from the farm to the plate. In Workshop on Impacts of globalization on agricultural production and marketing with focus on food quality, Tokyo (Japan), 22-24 Jan 2003. Japan FAO Association.

Singer, M., Bulled, N., Ostrach, B., \& Mendenhall, E. (2017). Syndemics and the biosocial conception of health. The Lancet, 389(10072), 941-950.

Sneyd, L. Q. (2013). Wild food, prices, diets and development: Sustainability and food security in urban Cameroon. Sustainability, 5(11), 4728-4759. https://doi.org/10.3390/su5114728

Sultana, F. (2012). Producing contaminated citizens: Toward a nature-society geography of health and wellbeing. Annals of the Association of American Geographers, 102(5), 1165-1172.

Trosper, R. L., \& Parrotta, J. A. (2012). Introduction: The growing importance of traditional forest-related knowledge. In Trosper R. L. \& Parotta, J.A. (Eds.), Traditional forest-related knowledge: sustaining communities, ecosystems and biocultural diversity. (pp. 1-36). Springer.

USAID. (2009). Senegal sub-regional conflict assessment. Management Systems International, Co. Retrieved from https://www.usaid.gov/sites/default/files/documents/1866/Senegal\%20Sub Regional\%20Conflict\%20Assessment_Final\%2012-30-09.pdf.

USAID, CILSS, \& USAID. (2016). The Republic of Senegal, ecoregions and topography of Senegal. West Africa: Land use and land cover dynamics. Retrieved from https://eros.usgs.gov/westafrica/ecoregionsand-topography/ecoregions-and-topography-senegal

Welch, C., Zhen, J., Bassène, E., Raskin, I., Simon, J. E., \& Wu, Q. (2018). Bioactive polyphenols in kinkéliba tea (Combretum micranthum) and their glucose-lowering activities. Journal of food and drug analysis, 26(2), 487-496. https://doi.org/10.1016/j.jfda.2017.05.009

Wood, S. A. (2018). Nutritional functional trait diversity of crops in south-eastern Senegal. Journal of Applied Ecology, 55(1), 81-91. https://doi.org/10.1111/1365-2664.13026

Yates-Doerr, E. (2015). The weight of obesity. University of California Press. 